Brantly, A. F. (2019) From Cyberspace to Independence Square: Understanding the Impact of Social Media on Physical Protest Mobilization During Ukraine's Euromaidan Revolution. Journal of Information Technology \& Politics, vol. 16, iss. 4, pp. 360-378. DOI: https://doi.org/10.1080/ 19331681.2019.1657047

Enikolopov, R., Makarin, A. and Petrova, M. (2020) Social media and protest participation: Evidence from Russia. Econometrica, vol. 88, iss. 4, pp. 1479-1514. DOI: 10.2139/ssrn.2696236

Karakaya, S. and Glazier, R. A. (2019) Media, information, and political participation: The importance of online news sources in the absence of a free press. Journal of Information Tecbnology \& Politics, vol. 16, iss. 3, pp. 290-306. DOI: https://doi.org/10.1080/19331681.2019.1645784

Tufekci, Z. and Wilson, C. (2012) Social media and the decision to participate in political protest: Observations from Tahrir square. Journal of Communication, vol. 62, iss. 1, pp. 363-379. DOI: http://dx.doi.org/10.1111/j.1460-2466.2012.01629.x

Submission date: 01.11.2021.

Гарбузняк Алина Юрьевна - кандидат филологических наук, доцент кафедры журналистики Московского гуманитарного университета. Адрес: 111395, г. Москва, ул. Юности, д. 5. Тел.: +7 (499) 374-60-91. Эл. адpec: a.garbuznyak@yandex.ru

Забиранко Валерия Игоревна - магистрант 2-го курса направления «Журналистика» Московского гуманитарного университета. Адрес: 111395, Россия, г. Москва, ул. Юности, А. 5. Тел.: +7 (499) 374-60-91. Эл. адрес: zabirankovaleri@yandex.ru

Garbuznyak Alina Yuryevna, Candidate of Philology, Associate Professor, Department of Journalism, Moscow University for the Humanities. Postal address: 5, Yunosti St., Moscow, Russian Federation, 111395. Tel.: +7 (499) 374-60-91. E-mail: a.garbuznyak@yandex.ru

Zabiranko Valeria Igorevna, Graduate Student, second year, academic programme "Journalism", Moscow University for the Humanities. Postal address: 5, Yunosti St., Moscow, Russian Federation, 111395. Tel.: +7 (499) 374-60-91. E-mail: zabirankovaleri@yandex.ru

DOI: $10.17805 /$ zpu.2021.4.20

\title{
Процесс социализации юношества посредством молодежных СМИ (на примере программы «ФИШКА» телекомпании «Ноябрьск 24»)
}

\author{
О. Е. КОХАНАЯ, Н. Ю. ЮРТАЕВ \\ МОСКОВСКИЙ ГУМАНИТАРНЫЙ УНИВЕРСИТЕТ
}

Авторы отмечают, что за последние два десятилетия в политике государства в отношении воспитания и организации культурного досуга детей и подростков произошли кардинальные изменения: развитие детско-юношеского общественного движения в современной России во взаимосвязи с развитием цифровых технологий, социальных сетей и отечественных молодежных СМИ, которые на новом этапе выступают фактором воспитания, формирования ценностей участников медиакоммуникации. Медиаобразование конвертирует полезные навыки и умения в профессиональные компетенции. Наиболее подвержена влиянию и быстрым изменениям самая активная часть общества - молодежь. Молодой человек получает информацию постоянно через журналы, газеты, сайты, 
книги, кино, шоу и т. д., благодаря полученной информации и формируются ценностные установки, нравственные основы и стереотипы. В связи с ослаблением контроля на рынке средств массовой информации, когда неконтролируемая информация передается подросткам, что подчас негативно сказывается на формировании моральных и нравственных ценностей подрастающего поколения, тема формирования имиджа подростка посредством сегмента детских и молодежных СМИ представляется особенно актуальной на современном этапе. Авторы статьи исследуют процесс трансформации механизмов коммуникации, выявляют роль СМИ в формировании имиджа российского подростка, тенденции медиапотребления молодежного рынка СМИ, представляют общую характеристику телепрограммы «Фишка» телеканала «Ноябрьск 24» и спецпроекты в рамках данной телепрограммы.

Ключевые слова: медиакоммуникация; цифровой иммунитет; медиаобразование; воспитание; коммуникативная компетентность; медиакультура; постправда; картина мира; поколение Z; возрастная группа медиаудитории; подростково-молодежная телепрограмма

\section{ВВЕАЕНИЕ}

$\mathrm{B}$ политике российского государства за последние 20 лет в отношении воспитания и организации культурного досуга детей и подростков произошли кардинальные изменения: во многих регионах открываются специализированные центры, такие как Международный детский центр «Артек», Всероссийский детский центр «Смена», Всероссийский образовательный центр «Сириус» и Ар., создаются детские и молодежные общественные организации. Их деятельность активно дублируется медиаресурсами. На прилавках магазинов появляются многочисленные детские журналы, на телеэкранах выходят познавательные передачи первого российского детского и юношеского телеканала «Бибигон» (сейчас он называется «Карусель»), новых российских телеканалов «Аетский мир», «Мульт», «Мультимания», «Радость моя», «Рыжий», также на отечественном телевидении функционируют зарубежные телеканалы: «Nickelodeon», «Baby TV», «Boomerang», «Cartoon Network», «Da Vinci», «Disney», «JimJam», «Nick Jr», «TiJi», «Gulli», при этом надо отметить, что количество зарубежных телеканалов значительно превосходит количество отечественных. В регионах России активно функционируют школьные печатные СМИ, телевидение, радио, конвергентные редакции, медиахолдинги, где школьники, юные журналисты, приобретают как первичные умения и навыки журналистского творчества, так и столь необходимые в эпоху цифровых медиа компетенции в сфере медиаобразования и медиакоммуникации (Коханая, 2018: Электронный ресурс). Ведутся научные исследования в области медиаобразования, публикуются научные сборники, учебники, монографии, проводятся научные форумы и конференции. В Московском педагогическом государственном университете 24-25 сентября 2021 г. прошла XII Международная научно-практическая конференция «Медиаобразование: стратегии развития - 2021» памяти Ирины Владимировны Жилавской, которая как ученый-исследователь с мировым признанием стояла во главе целого направления научной деятельности по медиаобразованию в системе формирования коммуникативной компетентности по медиаобразовательным технологиям и практикам. Вдохновленные ее идеями по медиаобразованию детей и молодежи, преподаватели и студенты кафедры журналистики Московского гуманитарного университета уже не один год исследуют данную научную тему и рассматривают ее как приоритетную (Головин, Коханая, 2018). 
Не все так лучезарно в сфере создания и трансляции телепередач для таких возрастных категорий, как подростки и юношество, поэтому, как нам представляется, интересен опыт подростково-молодежной телепрограммы «Фишка» города Ноябрьска Ямало-Ненецкого автономного округа, подвергшийся научному анализу в данной статье.

\section{СОВРЕМЕННАЯ МЕАИАКОММУНИКАЦИЯ И ПОКОАЕНИЕ Z}

Сегодняшние средства массовой информации обладают большим спектром возможностей для привлечения и удержания потенциального зрителя у экрана. Аинамично-визуализированные кадры, высокие звуковые частоты, входящие в разрез с привычными частотами, многочисленные повторы, гипнотическое мерцание и шумы, вводящие в транс, - это лишь некоторые способы переформатирования сознания детей. Американский психолог Альберт Бандура отметил уязвимость сознания как детей, так и взрослых перед высокой эффективностью современных технологий: «Ввиду широкого распространения телемоделирования, СМИ играют важную роль в формировании человеческого поведения и социальных отношений» (Бандура, 2000: 12). По мнению некоторых ученых, СМИ имеют важнейшее значение в реализации глобального проекта «превращения человека в манипулируемое существо» (Кара-Мурза, 2015: 51).

При широкомасштабном распространении Интернета на современном этапе происходят глобальные изменения в понятиях «коммуникация», «медийная культура общества». При явных достоинствах получения информации через Интернет (ее скорость, доступность, обширные объемы) с развитием новых информационных технологий очевидны и негативные последствия перемен, например манипуляция гражданским сознанием, информационная перенасыщенность пользователей, что приводит к снижению познавательной деятельности дичности, ухудшению памяти в сторону ее краткосрочности и фрагментарности. В целом виртуальная реальность способна вмешиваться в жизнь человека порой весьма агрессивно.

Современному обществу важен коммуникационный процесс, ведь благодаря ему происходит формирование межличностных связей, становление, развитие и функционирование социальных систем. Известный специалист в сфере социологии коммуникации В. П. Конецкая так определяет коммуникацию: «Коммуникация - социально обусловленный процесс передачи и восприятия информации в условиях межличностного и массового общения по разным каналам при помощи различных коммуникативных средств. Коммуникация не может начаться без потребности получателя в той информации, которая кодируется в сообщении» (Конецкая, 1997: 5). Как определяется в специализированном англо-русском словаре, «виртуальная коммуникация подразумевает общение с удаленным партнером или группой, опосредствованное компьютером или телекоммуникационными системами» (Йорген, 2000: 42). Исследователи В. А. Михайлов и С. В. Михайлов еще в 2004 г. выделяли следующие особенности данного типа коммуникации: «виртуальность, креативность, гипертекстуальность, интерактивность, глобальность, анонимность и мозаичность» (Михайлов, 2004: 34-35).

Говорить о молодежи в целом сложно, так как молодежь сама по себе неоднородна и теоретически делится на различные возрастные периоды. Сегодня возрастные границы молодежи закреплены в Основах государственной молодежной политики Российской Федерации на период до 2025 года, где установлено, что в дан- 
ную категорию входят лица от 14 до 30 лет¹. При этом возрастные границы внутри категории «молодежь» могут варьироваться. Известный российский социолог Б. А. Ручкин, например, выделял следующие возрастные периоды молодежного возраста: «подростковый возраст - до 18 лет, собственно молодежь - до 24 лет и “молодые взрослые" - с 25 лет до конца верхней возрастной границы» (Ручкин, 1998: 9).

С начала 2000-х гг. появляется так называемый поколенческий подход к исследованию аудитории: каждому новому поколению присваиваются различные обозначения (поколение X, Y и Z). Z обозначает современное поколение, которое отличается от предыдущих восприятием информации, концентрацией внимания. Отмечается, что современная молодежь очень быстро на все реагирует, может одновременно находиться в нескольких как виртуальных, так и реальном пространствах, например делать фотографии и «репостить» их друзьям, поддерживать виртуальную беседу в социальной сети «ВКонтакте» и одновременно общаться с находящимися рядом собеседниками. Однако при этом не способна сосредоточиться, сконцентрироваться на одном предмете или мысли, так как продумать ее детально времени нет.

Поколение Z не осваивает Интернет, оно уже рождается в эпоху цифровых коммуникаций и успешно пользуется благами IT-цивилизации. Современное поколение начинает прибегать к помощи интернет-ресурсов на ранних стадиях жизни, прежде чем начинает использовать в полной мере артикуляционно-речевой аппарат. С помощью цифровых технологий, уже без помощи и контроля взрослых, в три-четыре года ребенок самостоятельно получает необходимую информацию, это намного раньше, чем он начинает читать и писать. Весь вопрос в том, какую информацию он усваивает, ускоренно проходя этапы социализации посредством цифровых медиа: способствующую его интенсивному интеллектуальному, эмоционально-чувственному развитию или оставляющую его на уровне примитивности и инфантильности (Коханая, 2018: Электронный ресурс).

Цивилизационный подход в научных исследованиях отводит конкретному человеку с его особенностями, вкусами и предпочтениями центральное место в информационно-коммуникативных взаимодействиях социума. Современные технологии и средства связи воспринимаются как усиление личностных качеств человека, способствующие его постоянному обновлению. СМИ являются массовыми не из-за размера аудитории, а из-за способности концентрировать внимание большей части населения планеты в одно время и в одном месте. Как точно определяет сложившуюся социокультурную ситуацию декан факультета журналистики Московского государственного университета имени М. В. Аомоносова профессор Е. $\Lambda$. Вартанова, «аудитория СМИ уже не является гомогенной и представляет собой совокупность фрагментированных аудиторий, потребителей большого разнообразия медиапродуктов, которые предлагает современная российская медиаиндустрия» (Вартанова, 2006: 68).

Важно понимать, что мы живем в мире, где чуть ли не каждый день появляются новые медиапродукты с учетом различных аудиторных предпочтений и кардинально изменившиеся инструменты и способы получения информации. Если раньше информацию получали через письма, газеты, радио, то в наше время можно идти по улице в наушниках и слушать подкасты на темы, которые тебе интересны. Констатируем, что Интернет - это необъятная по величине площадка по интересам. 
Если подростку интересны советские фильмы, то большую часть информации он будет искать на просторах большой Всемирной паутины. Заходя на сайты, мы видим, что роботы-сканеры поисковой системы (например, Яндекс) считывают наши запросы и предпочтения. После того как культурные потребности подростка зафиксированы, ему автоматически на разных сайтах будет регулярно демонстрироваться небольшая реклама на тему его приватных запросов и желаний. В современном мире появилось множество способов и методов для получения информации. В Интернете можно мгновенно найти всю актуальную информацию, обновляющуюся в реальном времени. Подросток просыпается и засыпает с телефоном в руках и существует в принципиально иных системах общения, где сломаны коммуникационные барьеры, смешана реальность (Солдатова, Рассказова, Нестик, 2017: 342).

Как уже говорилось, современные исследователи пытаются анализировать особенности аудитории и через поколенческие теории. «В социальном измерении аудитория медиа стала преломляться через поколенческие теории, где каждому поколению свойственны особенные паттерны медиапотребления и медиаповедения» (Аникина, Ермошкина, Искаков, Кобзев, 2016: Электронный ресурс). «Несмотря на всю неоднозначность поколенческих теорий, понимание того, что “цифровая молодежь" отличается от “аналоговых взрослых", стало определять концептуализацию аудитории медиа и в целом академического дискурса», - считает известный специалист в области экономической социологии В. В. Радаев (Радаев, 2018: 29).

Аругая точка зрения у профессора Е. $\Lambda$. Вартановой: «Более радикальное, основанное на политических ориентациях разграничение аудитории медиа на "партию телевизора" и “партию Интернета" не нашло медиаметрического подтверждения, хотя теория формирования повестки дня получила развитие за счет концептуализации альтернативной и параллельной повесток дня, формируемых молодежной аудиторией в России» (Вартанова, 2014: 148). Практически мы все независимо от возраста ежедневно получаем информацию через социальные сети, через общение и даже через рекламу на уличных баннерах. «Человек медийный» так определяет Е. $\Lambda$. Вартанова образ современного человека, сформированного независимо от возраста существующей медиасредой, повесткой дня, новым типом коммуникационной практики (Вартанова, 2018: Электронный ресурс).

Требующей внимания представляется также мысль С. С. Бодруновой и А. А. Аитвиненко, рассматривающих формирование общественной «контрсферы», массовые волнения и политические протесты в России (и не только: например, арабская весна, выборы президента в Беларуси) через призму функционирования новых медиа: «развитие получило и изучение роли молодежи в организации протестов с помощью медиакоммуникаций» (Bodrunova, Litvinenko, 2013).

Важной особенностью медиапотребления современной молодежной аудитории является массовое падение интереса к чтению и доминирующий интерес к экранной культуре, при этом за внимание молодежной аудитории телевидение как экранный вид творческой деятельности (Смеюха, 2015) активно и неустанно борется с Интернетом. Справедливо наблюдение А. В. Аунаса: «В последние годы отмечается, что молодые люди являются активными пользователями социальных сетей и преимущественно через них узнают новости» (Аунас, 2018: Электронный ресурс). В процессе ценностного, нравственного формирования личности для создания некоего собственного имиджа молодые также обращаются к социальным сетям. 
«Типичны для пубертата эксперименты с собственной идентичностью, желание проигрывать разные социальные роли, “примерять" на себя различные "маски". Интернет-среда, форумы, мессенджеры, социальные сети дают молодежи массу возможностей для общения, поиска близких по интересу групп, для саморазвития и экспериментов с собственной идентичностью» (Кирьякова, 2017: 166). Аанные сервисы «позволяют пользователям конструировать свою виртуальную личность, наделяя ее желанными качествами и скрывая ее реальные характеристики, и превращаются для подростков в своеобразную тренировочную площадку» (Бабаева, Войскунский, Смыслова, 2000: 27).

\section{КОММУНИКАЦИОННЫЕ СООБЩЕСТВА: \\ САМООРГАНИЗАЦИЯ АЕТЕЙ И МОАОАЕЖИ}

Информационное пространство модифицируется, параллельно с ним перманентно развиваются и возрастают возможности юных пользователей. Цифровое поколение сегодня называют «глобальные дети» (Цымбаленко, 2014: 16), так как они имеют возможности межконтинентального общения и безграничного взаимодействия. Глобальность и неограниченная свобода выбора, независимость от взрослого поколения, равноправие в гендерном отношении и отсутствие физических недостатков в виртуальном пространстве предоставляют огромный спектр возможностей для развития и самореализации. Новая «безграничная» свобода требует постоянных усовершенствованных качеств и механизмов самообновления, саморегуляции и самоорганизации. Также юные пользователи испытывают необходимость в авторитетном мнении по интересующим их вопросам. Как показывает статистика, оценка фотогеничного «эксперта» с большим количеством подписчиков в социальных сетях имеет больший вес по сравнению с мнением родителей, друзей или учителей в школе. Интернет остается незаменимым механизмом постижения реальности через современные технологии и возможности.

Возможность беспрепятственной коммуникации подтолкнула подрастающее поколение к формированию информационно-коммуникативной цивилизации. Недостаток коммуникации, общения в реальной жизни в XXI в. восполняют социальные сети, где возникают все новые и новые молодые сообщества. Чаще всего их функция - быстрая, практически мгновенная передача важной, необходимой информации дистанционно. Но ведь информация может быть разнородной, в том числе вредоносной, экстремистской и проч. Способен ли ребенок отфильтровать ее, правильно расставить акценты, подвергнуть рефлексии лавину бесперебойного информационного потока? (Коханая, 2018: Электронный ресурс). В то же время подобная самоорганизация детей и молодежи в коммуникационные сообщества способствует отдалению от взрослых и ведет к их полной изоляции и ранней самостоятельности. Многообразие интересов и увлечений, активная деятельность, направленная на удовлетворение разнообразных запросов и интересов, обмен культурно-историческим опытом, формирование чувства ответственности, насыщенная деятельность, которая находится у всех на виду и в некоторых случаях является предметом подражания, - все эти черты характерны для саморазвивающихся сообществ.

При этом средства массовой коммуникации становятся не только механизмом реализации намеченных целей и поставленных задач, но и содействуют самореализации как конкретного индивида, так и его окружения в целом. Создается уни- 
кальная виртуально-реальная площадка, формируется независимая действительность, которая находит отражение в событиях реальной жизни.

Конкретная группа в силу воспитания, әрудиции, медиаграмотности, наличия навыков выживания в беспорядочном хаосе информационного шума следует по Авум путям развития. Первый - «высокий взлет» (происходит из-за четкой постановки и выполнения целей и задач, обмена актуальными, недавно сформировавшимися возможностями, новыми знаниями программирования и пользования цифровым обеспечением среди детей и молодежи и отсутствия консервативных, привычных взглядов со стороны взрослого поколения). Формируется самосознательное сообщество, которое расширяется и развивается благодаря нарастающему взаимодействию и обмену контентом, эмоциями, имеет определенный вектор к расширению пространственно-временных границ. Аругой вектор развития - «свободное падение» (негативный эффект воздействия раннего отдаления детей с несформировавшимся до конца сознанием от родителей, отсутствие привитых культурных и воспитательных норм, непонимание конечной цели объединения в конкретное сообщество, элементарное незнание в силу некомпетентности, непонимание дальнейших действий, нежелание развиваться) отсылает данное сообщество на более низкий уровень развития.

Отличительным признаком информационно-коммуникативных отношений является отсутствие демографических, гендерных и физических различий (национальность, пол, возраст, речевой акцент - все отличительные особенности растворяются в пространстве Всемирной паутины). Также характерной чертой является многоканальность получения информации: современный ребенок получает данные из разных источников, параллельно анализируя и сохраняя нужный контент. По статистке, главным источником информации остается Интернет, на втором месте школа и друзья. Аети больше присушиваются к учителям, чем к родителям, так как те не пользуются новыми технологиями, востребованными в школьной среде.

Надо отметить, что в 2000-х гг. молодежь была признана как особая возрастная группа медиаудитории. Выдающийся российский исследователь медиасферы и медиаобразовательных технологий И. В. Жилавская, концептуализируя проблемы медиаобразования современной молодежной аудитории, констатировала, что «ушла в прошлое прежняя система воспитания молодежи, в значительной степени утрачены и традиционные воспитательная и просветительская функции СМИ» (Жилавская, 2009: 225). И. В. Жилавская считала, что если речь заходит о детях и подростках, то медиаинформационная грамотность должна не только способствовать пониманию функции медиа, обеспечивать возможность самовыражения и формирования продвинутой социокультурной личности, но и включать в образовательную программу различные обучающие активности, направленные на осмысление своей гражданской ответственности и воспитание патриотизма. Аети являются полноценными участниками виртуального пространства и активными потребителями контента наравне со взрослыми. Главной опасностью существования в данной среде является равноправие на информацию, общая доступность, отсутствие опыта в силу возраста и незащищенность детей от вредоносного источника информации с непредсказуемыми последствиями.

XXI век - время гаджетов и Интернета, век информации, новых компетенций и технологий, где основной валютой считаются знания и скорость. Здесь действуют такие же законы, как и на Олимпийских играх: правильно выбранная тактика за 
минимально отведенное время гарантирует победу. Создание первоисточника главный козырь в информационных войнах. Текущее время характеризуется не только постоянно увеличивающимся в геометрической прогрессии трафиком, но и подменой истинных суждений, возникновением таких понятий, как «правда» и «постправда». В соответствии с непоколебимыми установками журналистского кодекса в основе любой новости лежит факт, далее следует интерпретация, т. е. доведение информации в общедоступном формате до массовой аудитории, затем - оценка эксперта. Соответственно, в основе информационного повода лежит правдивое событие. В эпоху цифровой экономики «достоверность» зачастую уступает место «фейку». Аругими словами, первоисточником будущей новости становится выдуманное, искусственно скомбинированное событие, нацеленное на вариативность интерпретаций. Несколько спикеров с противоположным мнением кратко выражают свою позицию в отношении случившегося, а далее экспертный контент вбрасывается в неподготовленную аудиторию, что вызывает әмоциональную, необдуманную реакцию.

Коллективное бессознательное с помощью ярко выраженных, экспрессивных комментариев превращает пустышку в реальную новость, финал которой определят рейтинги просмотров, лайки и ничем не подтвержденные, так называемые мнения экспертов, т. е. некие субъективные точки зрения напористых, фотогеничных личностей, как правило, не имеющие никакой доказательной базы. «И вот уже новейшие информационные технологии, призванные упростить общение между людьми и народами, значительно расширить наши возможности в получении и распространении информации, т. е. в понимании друг друга, превращаются в оружие массового поражения сознания, подменяя реальность симулякрами, заполоняя медиапространство постправдой», - констатирует известный ученый, журналист Ю. А. Головин (Головин, 2020: 39-40).

Не каждый пользователь владеет навыком фильтрации предлагаемого ресурсами Всемирной паутины контента. Полностью оградить себя от беспорядочного потока информации невозможно, так как большинство необходимых операций ежедневно совершается благодаря использованию современных технологий и сети Интернета. Чтобы уберечь себя от деструктивной информации, человеку необходимы компетенции, сформированные на основе полученного медиаобразования. Большинство читателей, зрителей, слушателей способны отделить «положительную» информацию от «негативной», но для правильной ориентации в мире медиа этого недостаточно.

\section{ИНФОРМАЦИОННО-РАЗВАЕКАТЕАЬНАЯ ПРОГРАММА «ФИШКА » КАК ФЕНОМЕН ОТЕЧЕСТВЕННЫХ МОАОДЕЖНЫХ СМИ}

Молодежные СМИ являются для подростка примером: школьнику интереснее читать заметки, статьи, смотреть телевизионные программы там, где с ним общаются на одном языке, ему интереснее получать новую информацию от своего же сверстника. Молодежными средствами массовой информации являются «те печатные, аудиовизуальные и электронные издания, которые: а) ориентированы на возраст аудитории, ограниченный рамками 15-29 лет; б) используют в своей практике особые экстралингвистические и лингвистические контактоустанавливающие средства (среди них особняком стоит молодежный жаргон); в) освещают актуальную для молодежи информацию, соответствующую ее интересам и внутреннему 
миропониманию» (Гайдамак, 2010: 155-156). Журналистика для молодежи, будучи специфическим социокультурным институтом, является әффективным инструментом социализации и инкультурации молодежи, передачи опыта предыдущих поколений, приобщает ее к культурным традициям отечества, цивилизации в целом, формирует картину мира юного реципиента.

Сегодня молодежная журналистика многообразна по направлениям, стилям и жанрам, представлена в различных средствах массовой коммуникации. «Фишка» - это информационно-развлекательная еженедельная телевизионная программа для подростков и молодежи города Ноябрьска Ямало-Ненецкого автономного округа. Первый ее выпуск стартовал на канале «Ноябрьск 24» 15 мая 2015 г. В программе представлены события из жизни молодежи: школа, спорт, музыка, субкультурные объединения, развлечения, проблемы современности глазами подростков. Авторы сюжетов - обычные ноябрьские школьники. Именно они рассказывают своим сверстникам о самых интересных молодежных событиях Ноябрьска.

Еженедельная информационно-развлекательная программа «Фишка» выходит каждую пятницу в 20 часов 20 минут на телеканале «Ноябрьск 24». Молодежная редакция программы входит в дирекцию средств массовых коммуникаций издательского дома «Благовест», который практически является мультимедийным медиахолдингом, в состав которого входят Аирекция средств массовых коммуникаций (группа СМИ), «Мастерская печати» (полиграфическая и сувенирная продукция), рекламные агентства «Город» и «Экипаж» (изготовление и размещение наружной рекламы, рекламы в СМИ). Сегодня медиахолдинг работает в городах Ноябрьске, Муравленко, Губкинском и Пуровском районах Ямала.

С 1 августа 2014 г. ИА «Благовест» запустил собственный круглосуточный информационный канал «Ноябрьск 24», который вскоре стал доступен во всех мобильных и других скрин-устройствах по адресу N24.RU, а через два месяца «Ноябрьск 24» появился во всех кабельных сетях города.

На канале «Ноябрьск 24» внедрена уникальная стратегия баланса картины дня. Она включает 35 основных тематик, интересующих аудиторию, редакция «балансирует» выпуск контента в соответствии с ними. «Ноябрьск 24»- единственное в регионе СМИ, которое показывает, что происходит в течение дня в городе, округе, области: до 20\% информации уделяется событиям ЯНАО и Тюменской области - Тюмени. Кроме того, аудитория круглосуточного информационного канала «Ноябрьск 24», в полном объеме, без монтажа, в рубрике «Без комментариев» может увидеть видео с совещаний и встреч, которые происходят в администрации города, заседаний Городской думы, а также с различных культурных, спортивных, общественных мероприятий. Так, в каждом часе текущий выпуск новостей дополняется новыми фактами, подробностями, оперативной информацией, а в вечернем выпуске новостей подводятся итоги дня.

В составе редакции телепрограммы «Фишка» работают 3 штатных специалиста - автор и режиссер, режиссер монтажа, оператор и 15 внештатных юных корреспондентов. Редакционную политику телепрограммы «Фишка» можно выразить словами молодого исследователя Н. А. Андреевой в ее выступлении на научной конференции «Проблемы массовой коммуникации: новые подходы»: «определенное заданное направление деятельности редакции относительно происходящих в мире событий и их освещения в конкретном СМИ» (Андреева, 2011: Электронный ресурс). 
Попутно осуществляется формирование имиджа подростка, столь необходимое каждому в процессе становления личности. «Имидж подростка представляет собой тот образ, который создается в восприятии окружающих людей. Вполне естественно, что подростку постоянно хочется выделиться из толпы, чтобы иметь ярко очерченный образ, будь то позитивный или негативный» (Омарова, 2016: Электронный ресурс). «В виду того что понятия об имидже складываются у подростков, как правило, разрозненно, носят спонтанный, несистематизированный характер, часто подростки не задумываются о своем образе как об имидже в его целостном понимании» (Шепель, 2002: 389). Осмыслению этого и способствует журналистская творческая деятельность в телепрограмме «Фишка».

Основной задачей редакции является производство и выпуск информационноразвлекательного проекта «Фишка», а также работа «Журналистского класса», в рамках которого школьники получают опыт практической работы на телевидении, узнают всю телевизионную «кухню», прежде чем связать с журналистикой свою жизнь. А это, в свою очередь, помогает определиться с выбором будущей профессии. Так, корреспонденты молодежной редакции Наталья Крючек и Никита Плугарь стали в 2016 г. студентами кафедры журналистики Московского гуманитарного университета; в 2020 г. успешно его окончили и работают на телеканале «Москва 24»: Наталья - в отделе экономики, Никита - в новостном отделе, уже пригласили на практику студентов своей родной кафедры. Таким образом, эстафета поколений в тележурналистике, начатая в Ноябрьске, продолжается в Москве. Аа и один из авторов данной статьи, уже магистрант кафедры журналистики МосГУ Никита Юртаев, тоже поступил в 2017 г. в наш университет, пройдя путь от юнкора в ноябрьской «Фишке» до магистранта московского университета.

Телепрограмма «Фишка» имеет хронометраж 25 минут. Название программы не случайное. Фишка - это не только сленговое слово, которое обозначает некую особенность, изюминку. Оно обозначает и игровой элемент, на котором строится формат программы. Правила игры просты. Каждый раз ведущие программы собираются вместе для того, чтобы решить, на какие съемки отправится каждый из них. Традиционно они подбрасывают фишку, кто ее поймает, тот и определяет, кому и куда на этот раз.

Ведущие телепрограммы «Фишка», четыре человека, они же авторы сюжетов, появляются только в начале и в конце программы, переходы между сюжетами решаются фотозаставками с использованием графики.

В каждой программе представлено четыре сюжета - это могут быть репортажи, постановочные или тематические сюжеты, портретные очерки, опросы. Характерной особенностью проекта является тот факт, что все сюжеты выполнены в режиме life-to-tape, когда журналист во время всего сюжета находится в кадре, принимает участие в событиях, соответственно, отсутствует закадровый текст.

Телепрограмма «Фишка» также разрабатывает специальные спецпроекты, направленные на формирование имиджа современного подростка. На данный момент в разработке находятся несколько спецпроектов, связанных с перспективами развития региона, направленных на патриотическое и эстетическое воспитание молодежи, предполагающих участие редакции телепрограммы в региональных мероприятиях по профориентации. Проекты разрабатываются с учетом приоритетных направлений молодежной политики региона и страны в целом. 


\section{ЗАКАЮЧЕНИЕ}

Процесс ценностного становления и имиджевого формирования осуществляется путем самостоятельного создания подростками серии тематических спецпроектов, направленных на воспитание, формирование и развитие нравственного потенциала подростка на базе еженедельной информационно-развлекательной программы «Фишка». Спецпроекты данной телепрограммы помогают реализации творческой составляющей, становлению личности, что делает школьника более самостоятельным, устойчивым по отношению к негативным тенденциям, которые оказывают большое влияние на процесс его личностного формирования, определения им базисных нравственных ценностей.

Таким образом, молодежные средства массовой информации являются одной из ключевых платформ социализации, инкультурации, развития коммуникативных способностей, формирования ценностных ориентаций, гражданской позиции (Коханая, 2019: 456), имиджевой составляющей, наконец, воспитания подрастающего поколения.

\section{ПРИМЕЧАНИЕ}

1 Распоряжение Правительства РФ от 29 ноября 2014 г. № 2403-р «Об утверждении Основ государственной молодежной политики Российской Федерации на период до 2025 года» [Электронный ресурс]// Официальный интернет-портал правовой информации. URL: http:// publication.pravo.gov.ru/Document/View/0001201412080039?index=15\&rangeSize=1 (дата обращения: 15.10.21).

\section{СПИСОК АИТЕРАТУРЫ}

Аникина, М. Е., Ермошкина, Т. А., Искаков, А. З., Кобзев, М. В. (2016) Восприятие длинных текстов поколением «цифровых островитян» [Электронный ресурс] // Медиаскоп. № 1. URL: http:// www.mediascope.ru/node/2089 (дата обращения: 13.10.2021).

Андреева, Н. А. (2011) Влияние редакционной политики на формирование образов телеведущих [Электронный ресурс]// Коммуникация в современном мире : материалы Всерос. науч.-практ. конф. «Проблемы массовой коммуникации: новые подходы», 27-28 октября 2011 г. : в 2 ч. Ч. 27 под общ. ред. В. В. Тулупова. 93 с. С. 3-10. URL: http://programma.x-pdf.ru/ 16politologiya/338067-1-kommunikaciya-sovremennom-mire-materiali-vserossiyskoy-nauchnoprakticheskoy-konferencii-problemi-massovoy-kommunikacii.php (дата обращения: 13.10.2021).

Бабаева, Ю. А., Войскунский, А. Е., Смыслова, О. В. (2000) Интернет: воздействие на личность // Гуманитарные исследования в Интернете / под ред. А. Е. Войскуновского. М. : Можайск-Терра. 420 с. С. 11-39.

Бандура, А. (2000) Теория социального научения. СПб. : Евразия. 320 с.

Вартанова, Е. $\Lambda$. (2006) Современный медиабизнес и фрагментирующиеся аудитории // Экономика и менеджмент СМИ. Ежегодник 2005 / под ред. Е. $\Lambda$. Вартановой. М. : МГУ. 82 с. C. 59-81.

Вартанова, Е. $\Lambda$. (2014) Постсоветские трансформации российских СМИ и журналистики. М. : Медиа-Мир. 276 с.

Вартанова, Е. $\Lambda$. (2018) Человек медийный: как создается и распространяется информация в цифровую эпоху? [Электронный ресурс] : лекция 26.11.2018. URL: http://www.journ. msu.ru/about/calendar/26655/ (дата обращения: 13.10.21).

Гайдамак, А. А. (2010) PR-сопровождение молодежных СМИ Санкт-Петербурга: теоретико-методологические основы исследования // Известия Уральского государственного университета. Сер. 1. Проблемы образования, науки и культуры. № 6 (85). Ч. 2. С. 154-161.

Головин, Ю. А. (2020) Феномен постправды в условиях гибридных войн [Электронный ресурс] // Высшее образование для XXI века. Цифровая трансформация общества: новые 
возможности и новые вызовы. Сборник статей : в 2 т. Т. 2. XVI Междунар. науч. конф., Московский гуманитарный университет, 18-20 ноября 2020 г. : доклады и материалы / под общ. ред. И. М. Ильинского. М. : ИзА-во МосГУ. 492 с. С. 36-40.

Головин, Ю. А., Коханая, О. Е. (2018) Иитературно-художественные журналы и детская пресса как отечественный социокультурный феномен : монография. М. : ИзА-во МосГУ. 168 с.

Аунас, А. В. (2018) Наблюдение за потреблением информационного контента студентами факультета журналистики МГУ [Электронный ресурс] // Медиаскоп. № 4. URL: http:// www.mediascope.ru/2483 (дата обращения: 15.10.2021).

Жилавская, И. В. (2009) Медиаобразование молодежной аудитории. Томск : Изд-во ТИИТ. 322 с.

Йорген, Х. (2000) Англо-русский словарь компьютерных и интернет-терминов / Computer \&amp; Internet English-Russian Dictionary. M. : Moscow International Publishers, L\&H Publishing Co. 416 c.

Кара-Мурза, С. Г. (2015) Манипуляция сознанием. Век ХXI. М. : Алгоритм. 640 с.

Кирьякова, Н. А. (2017) Влияние социальных сетей на развитие коммуникативных способностей подростков // Концепт. № 29. С. 161-168.

Конецкая, В. П. (1997) Социология коммуникаций. М. : Международный университет бизнеса и управления. 304 с.

Коханая, О. Е. (2018) Социокинетика детства: взаимодействие детских общественных объединений с детской прессой [Электронный ресурс]// Международный электронный научно-образовательный журнал «Медиа. Информация. Коммуникация». № 26. MПГУ. URL: http:// mic.org.ru/new/708-sotsiokinetika-detstva-vzaimodejstvie-detskikh-obshchestvennykhob-edinenij-s-detskoj-pressoj (дата обращения 13.10.2021).

Коханая, О. Е. (2019) Информационно-коммуникативная активность детей и подростков: трансформация механизмов коммуникации [Электронный ресурс]// Моисеевские чтения: Культура как фактор национальной безопасности : доклады и материалы Общерос. (национальной) науч. конф. / под ред. А. В. Костиной, В. А. Аукова. М. : ИзА-во МосГУ. 517 с. С. $454-462$.

Михайлов, В. А., Михайлов, С. В. (2004) Особенности развития информационно-коммуникативной среды современного общества // Актуальные проблемы теории коммуникации : совместный рецензируемый сб. науч. трудов. СПб. : Изд-во СПбГПУ, 2004. С. 34-52.

Омарова, Э. М. (2016) Роль семьи и школы в формировании позитивного имиджа подростка // Современные наукоемкие технологии. № 4 (ч. 1). C. 167-171. URL: https:// top-technologies.ru/ru/article/view?id=35797 (дата обращения: 13.10.2021).

Радаев, В. В. (2018) Миллениалы на фоне предшествующих поколений: эмпирический анализ // Социологические исследования. № 3. С. 15-33.

Ручкин, Б. А. (1998) Молодежь и становление новой России: доклад Правительству о положении молодежи в 1993, 1994, 1996 гг. исследователей НИЦ// Социологические исследования. № 5.90 с.

Смеюха, В. В. (2015) Чему учит современное телевидение? // Преподаватель высшей школы в XXI веке : труды Междунар. науч.-практ. интернет-конф. Ростов-на-Аону, 12 января -30 июня 2015 года. Сб. 12. Ростов-на-Аону : Ростовский гос. ун-т путей сообщ. 426 с. C. 267-275.

Солдатова, Г. У., Рассказова, Е. И., Нестик, Т. А. (2017) Цифровое поколение России: компетентность и безопасность. М. : Смысл. 342 с.

Цымбаленко, С. Б. (2014) Медийный потрет юного москвича. М. : Аига юных журналистов. 72 с.

Шепель, В. М. (2002) Имиджелогия: секреты личного обаяния. М. : Народное образование. 474 c.

Bodrunova, S. S., Litvinenko, A. A. (2013) New Media and Political Protest: The Formation of a Public Counter-Sphere in Russia, 2008-2012 // Russia's Changing Economic and Political 
Regimes: The Putin Years and Afterwards / eds. A. Makarychev, A. Mommen. London : Routledge. 142 p. Pp. 29-65.

Aата поступления: 17.10 .2021 2.

\author{
THE PROCESS OF SOCIALIZATION OF YOUTH THROUGH YOUTH MEDIA \\ (ON THE EXAMPLE OF THE "FISHKA" PROGRAM \\ OF THE TV COMPANY “NOYABRSK 24”) \\ O. E. KOKHANAYA, N. YU. YuRTAEV \\ MOSCOW UNIVERSITY FOR THE HUMANITIES
}

The authors note that over the past two decades, cardinal changes have taken place in the state policy in relation to the upbringing and organization of cultural leisure for children and adolescents: the development of children's and youth social movement in modern Russia combined with developing digital technologies, social networks and domestic youth media. At the new stage, they act as a factor of education and the formation of values of participants in media communication. Media education converts useful skills and abilities into professional competencies. The most active part of society - the youth - is most subject to influence and rapid changes. A young person receives information constantly through magazines, newspapers, websites, books, movies, shows and so on; thanks to the information received, value attitudes, moral foundations and stereotypes are formed. In connection with the weakening of control in the mass media market, when uncontrolled information is transmitted to adolescents, which sometimes negatively affects the formation of moral and ethical values of the younger generation, the issue of shaping the image of a teenager through the segment of children's and youth media seems to be especially relevant at the present stage. The authors of the article investigate the process of transformation of communication mechanisms, identify the role of the media in shaping the image of a Russian teenager, identify trends in media consumption of the youth media market, present a general description of the "Fishka" TV program on the Noyabrsk 24 TV channel and special projects within the framework of this TV program.

Keywords: media communication; digital immunity; media education; upbringing; communicative competence; media culture; post-truth; picture of the world; generation Z; age group of media audience; teenage and youth TV program

\title{
REFERENCES
}

Anikina, M. Ye., Ermoshkina, T. A., Iskakov, D. Z. and Kobzev, M. V. (2016) Vospriyatiye dlinnykh tekstov pokoleniyem "tsifrovykh ostrovityan" Mediaskop, no. 1 [online] Available at: http://www.mediascope.ru/node/2089 (accessed: 13.10.2021). (In Russ.).

Andreeva, N. A. (2011) Vliyaniye redaktsionnoy politiki na formirovaniye obrazov televedushchikh. In: Kommunikatsiya v sovremennom mire: Materialy Vserossiyskoy naucbno-prakticheskoy konferentsii "Problemy massovoy kommunikatsii: novyye podkbody", October 27-28, 2011. In 2 parts. Part 2 / ed. by V. V. Tulupov. 93 p. Pp. 3-10 [online] Available at: http://programma.x-pdf.ru/16politologiya/338067-1-kommunikaciya-sovremennom-mire-materialivserossiyskoy-nauchno-prakticheskoy-konferencii-problemi-massovoy-kommunikacii.php (accessed: 13.10.2021). (In Russ.).

Babaeva, Yu. D., Voiskunsky, A. E. and Smyslova, O. V. (2000) Internet: vozdeystviye na lichnost'. In: Gumanitarnyye issledovaniya v Internete/ ed. A. E. Voiskunovsky. Moscow, MozhaiskTerra. 420 p. Pp. 11-39. (In Russ.). Russ.).

Bandura, A. (2000) Teoriya sotsial'nogo naucheniya. St. Petersburg, Eurasia. 320 p. (In

Vartanova, E. L. (2006) Sovremennyy mediabiznes i fragmentiruyushchiyesya auditoria. Ekonomika i menedzhment SMI. Yezhegodnik 2005 / ed. by E. L. Vartanova. Moscow, Moscow State University. 82 p. Pp. 59-81. (In Russ.). 
Vartanova, E. L. (2014) Postsovetskiye transformatsii rossiyskikb SMI i zburnalistiki. Moscow, Media World. 276 p. (In Russ.).

Vartanova, E. L. (2018) Chelovek mediynyy: kak sozdayetsya i rasprostranyayetsya informatsiya $v$ tsifrovuyu epokbu? Lecture 26.11.2018. [online] Available at: http://www.journ.msu.ru/ about/calendar/26655/ (accessed: 13.10.2021). (In Russ.).

Gaidamak, D. A. (2010) PR-soprovozhdeniye molodozhnykh SMI Sankt-Peterburga: teoretiko-metodologicheskiye osnovy issledovaniya. Izvestiya Ural'skogo gosudarstvennogo universiteta. Seria 1. Problems of education, science and culture, no. 6 (85), part 2, pp. 154-161. (In Russ.).

Golovin, Yu. A. (2020) Fenomen postpravdy v usloviyakh gibridnykh voyn. In: Vyssbeye obrazovaniye dlya XXI veka. Tsifrovaya transformatsiya obshchestva: novyye vozmozhnosti $i$ novyye vyzovy. Digest of articles. In 2 vols. XVI International Scientific Conference, Moscow University for the Humanities, November 18-20, 2020: Reports and materials / ed. by I. M. Ilyinsky. Moscow, Moscow Univ. for the Humanities. Vol. 2. 492 p. Pp. 36-40.

Golovin, Yu. A. and Kokhanaya, O. E. (2018) Literaturno-kbudozhestvennyye zhurnaly $i$ detskaya pressa kak otechestvennyy sotsiokul'turnyy fenomen. Moscow, Moscow Univ. for the Humanities. 168 p. (In Russ.).

Dunas, D. V. (2018) Nablyudeniye za potrebleniyem informatsionnogo kontenta studentami fakul'teta zhurnalistiki MGU. Mediaskop, no. 4. [online] Available at: http://www.mediascope. $\mathrm{ru} / 2483$ (accessed: 13.10.2021). (In Russ.).

Zhilavskaya, I. V. (2009) Mediaobrazovaniye molodezbnoy auditorii. Tomsk, TIIT. 322 p. (In Russ.).

Yorgen, H. (2000) Anglo-russkiy slovar' komp'yuternykb i Internet-terminov / Computer \&amp; Internet English-Russian Dictionary. Moscow, L\&H Publishing Co. 416 p.

Kara-Murza, S. G. (2015) Manipulyatsiya soznaniyem. Vek XXI. Moscow, Algorithm. 640 p. (In Russ.).

Kiryakova, N. A. (2017) Vliyaniye sotsial'nykh setey na razvitiye kommunikativnykh sposobnostey podrostkov. Kontsept, no. 29, pp. 161-168. (In Russ.).

Konetskaya, V. P. (1997) Sotsiologiya kommunikatsiy. Moscow, International University of Business and Management. 304 p. (In Russ.).

Kokhanaya, O. E. (2018) Sotsiokinetika detstva : vzaimodeystviye detskikh obshchestvennykh ob»yedineniy s detskoy pressoy. Mezhdunarodnyy elektronnyy naucbno-obrazovatel'nyy zburnal "Media. Informatsiya. Kommunikatsiya», no. 26 [online] Available at: http://mic.org.ru/ new/708-sotsiokinetika-detstva-vzaimodejstvie-detskikh-obshchestvennykh-ob-edinenij-s-detskoj-pressoj (accessed: 13.10.2021). (In Russ.).

Kokhanaya, O. E. (2019) Informatsionno-kommunikativnaya aktivnost' detey i podrostkov: transformatsiya mekhanizmov kommunikatsii. Moiseyevskiye cbteniya: Kul' tura kak faktor natsional' noy bezopasnosti: reports and materials of the All-Russian (national) scientific conference / ed. by A. V. Kostina and V. A. Lukov. Moscow, Moscow Univ. for the Humanities. 517 p. Pp. 454-462 [online] Available at: http://publications.mosgu.ru/index.php/main/catalog/book/ 14 (accessed: 13.10.2021). (In Russ.).

Mikhailov, V. A. and Mikhailov, S. V. (2004) Osobennosti razvitiya informatsionno-kommunikativnoy sredy sovremennogo obshchestva. In: Aktual'nyye problemy teorii kommunikatsii: Actual problems of communication theory: Joint peer-reviewed collection of the Department of Political Science of St. Petersburg State Polytechnic University and the Coordinating Council of the Russian Communication Association. St. Petersburg, Saint Petersburg State Polytechnic University. 362 p. Pp. 34-52. (In Russ.).

Omarova, E. M. (2016) Rol' sem'i i shkoly v formirovanii pozitivnogo imidzha podrostka. Sovremennyye naukoyemkiye tekbnologii, no. 4, part 1, pp. 167-171 [online] Available at: https://top-technologies.ru/ru/article/view?id=35797 (accessed: 13.10.2021). (In Russ.).

Radaev, V. V. (2018) Millenialy na fone predshestvuyushchikh pokoleniy: empiricheskiy analiz. Sotsiologicheskiye issledovaniya, no. 3, pp. 15-33. (In Russ.). 
Ruchkin, B. A. (1998) Molodezh' i stanovleniye novoy Rossii : doklad Pravitel'stvu o polozhenii molodezhi v 1993, 1994, 1996 gg. issledovateley NITS. Sotsiologicheskiye issledovaniya, no. 5. 90 p. (In Russ.).

Smeyukha, V. V. (2015) Chemu uchit sovremennoye televideniye? In: Prepodavatel' vyssbey shkoly $v$ XXI veke: Trudy Mezbdunarodnoy nauchno-prakticheskoy Internet-konferentsii. Rostov State Transport University. Rostov-on-Don, January 12 - June 30, 2015. Collection 12. Rostov-on-Don, Rostov State Transport University. 426 p. Pp. 267-275. (In Russ.).

Soldatova, G. U., Rasskazova, E. I. and Nestik, T. A. (2017) Tsifrovoye pokoleniye Rossii: kompetentnost' i bezopasnost'. Moscow, Smysl. 342 p. (In Russ.).

Tsymbalenko, S. B. (2014) Mediynyy potret yunogo moskvicha. Moscow, League of Young Journalists. 72 p. (In Russ.).

Shepel, V. M. (2002) Imidzbelogiya : sekrety lichnogo obayaniya. Moscow, Public education. 474 p. (In Russ.).

Bodrunova, S. S. and Litvinenko, A. A. (2013) New Media and Political Protest: The Formation of a Public Counter-Sphere in Russia, 2008-2012. In: Russia's Changing Economic and Political Regimes: The Putin Years and Afterwards / ed. by A. Makarychev and A. Mommen. London, Routledge. 142 p. Pp. 29-65. (In Eng.).

Submission date: 17.10.2021.

Коханая Ольга Евгеньевна - доктор культурологии, доцент, профессор кафедры журналистики Московского гуманитарного университета. Адрес: 111395, Россия, г. Москва, ул. Юности, д. 5. Тел.: +7 (495) 374-60-91. Эл. адрес: kokhanaya@mail.ru

Юртаев Никита Юрьевич - магистрант кафедры журналистики Московского гуманитарного университета. Адрес: 111395, Россия, г. Москва, ул. Юности, д. 5. Тел.: +7 (499) 374-60-91. Эл. адpec: nikita.yurtaev1998@mail.ru

Kokhanaya Olga Evgenyevna, Doctor of Cultural Studies, Associate Professor; Professor, Department of Journalism, Moscow University for the Humanities. Postal address: 5, Yunosti St., Moscow, Russian Federation, 111395. Тел.: +7 (495) 374-60-91. E-mail:kokhanaya@mail.ru

Yurtaev Nikita Yuryevich, Graduate Student, Department of Journalism, Moscow University for the Humanities. Postal address: 5, Yunosti St., Moscow, Russian Federation, 111395. Tel.: +7 (499) 374-60-91. E-mail: nikita.yurtaev1998@mail.ru 